\title{
Landscape Design and Research of Future Urban Theme Parks
}

\author{
Junqiao Shi \\ Panzhihua University,Sichuan, China \\ 429125625@qq.com
}

\begin{abstract}
Keywords : City Theme Park; Problematic Follow-up Development; Future Development Trend
\end{abstract}

\begin{abstract}
City Theme Park in the future focuses its the final service objects on people, developing the unique connotation and landscape environment full of rich experience in order to adapt to the future development trend of urban theme parks and maintain the momentum of sustainable development. City Theme Park is a wonderful place which expresses people's best wish of the economic life and spiritual culture. And the landscape characteristic of the future City Theme Park is the necessary condition to shape the window-effect of the city. Future City Theme Park, as the perceived image of urban culture and regional culture need to achieve the win-win benefits between economy and culture and orientate cultural characteristics of the theme precisely so as to create City Theme Park successfully in accord with the needs of the times.
\end{abstract}

\section{Introduction}

City Theme Park is originated in the United States in 1955. Walt Disney, an American with his outstanding creativity successfully established the world's first theme park, Disneyland in Los Angeles, California. Since it integrates recreation, scientific Expo, community centers and theatrical performances as a whole, Disneyland is a good place of beauty and wonders for the parents and children to enjoy and share the family happiness, which has attracted a large number of tourists from home and abroad. Thus it has obtained a huge success. The success of Disney has stimulated the development of theme parks around the world, such as the Madurodam in Netherlands, The Seagaia Ocean Dome (located in the city of Miyazaki on the Japanese island of Kyushu), the Marine World of the Gold Coast in Australia, Sentosa in Singapore, EverLand in South Korea and Ocean Park in Hongkong, all of which have achieved great success. The global theme parks are classified as categories shown in the following Table 1

\section{Classification of Global Theme Parks}

\begin{tabular}{|c|c|}
\hline Themes Classification & Functions Classification \\
\hline $\begin{array}{c}\text { traditions and national cultures } \\
\text { demonstrating theme parks }\end{array}$ & $\begin{array}{c}\text { theme parks for appreciation of } \\
\text { stationary scenes }\end{array}$ \\
\hline $\begin{array}{c}\text { animals and plants appreciation } \\
\text { theme parks }\end{array}$ & $\begin{array}{c}\text { theme parks for appreciation of } \\
\text { stationary scenes }\end{array}$ \\
\hline $\begin{array}{c}\text { Exotic Theme Parks } \\
\text { Literature and Cultural heritage } \\
\text { Theme Parks }\end{array}$ & \begin{tabular}{c} 
Activity Theme Parks \\
\hline Film and Television Theme Parks
\end{tabular} \\
$\begin{array}{c}\text { Challenging Entertainments Theme } \\
\text { parks }\end{array}$ \\
\hline
\end{tabular}

Table 1 Classification of Global Theme Parks 


\section{Innovation Shortage Reflected among Most of the Theme Parks landscape design}

Theme is the soul of theme parks and innovation is the life of the theme park. Theme park needs to highlight the theme, along with the distinctive features, such as the "Universal Studios" in Hollywood. The reason of its forever prosperity is that with an irreplaceable unique personality, it represents the Hollywood film and television entertainment culture. If lacking characteristics and imitating the construction from every aspect, the theme park will be similar to each other and inevitably distract tourists, thus making themselves difficult to escape failure. This is precisely the most fundamental reason for the loss or even bankruptcy of most of theme parks around the world in the 1990s.

\section{The Passive Management Mode Adoption}

Passive management mode is the main reason why many theme parks cannot achieve sustainable development. For example, the majority of Chinese theme park adopts the passive management mode, but not requires every tourist to participate in the performance.The large performances in OCT in Shenzhen, China, every night attract a large number of visitors to enjoy. It is obvious that the large show can benefit from this mode of operation. On the one hand, if the tourists only want to watch, they will stay for a period of time in the park in order to save energy. Then visitors will naturally have dietary demands when lingering for a long time, thus resulting in more economic benefits. On the other hand, the per capita area needed by tourists when watching is smaller than that of participation in the performance, which in all is conducive to accommodate more visitors in each venue. But there is a drawback: just watching without participation in activities can not maintain the long-term interest of tourists.

\section{The Problematic Follow-up Development in Most of the Theme Park landscape design}

An artificial lake surface area of Disneyland, in Los Angeles, America is 150 acres larger than that of Shanghai Xijiao Park. In addition, it nurtured the forest and swamp full of many waterfowl and aquatic animals with an area of 30 square kilometers carefully. In 1970s, Singapore opened up 4272 mu with 41 kilometers length from east to west, $25 \mathrm{~km}$ width from north to south in the expensive land in order to complete the construction of Sentosa Theme Park with tens of millions investments. And then it set up more than 100 hectares of land to build the Crocodile Park and the world's largest bird park. However, this was just one of the successful cases. Comparatively speaking, China's theme park started late and most investment of the project is relatively small, limiting the park's subsequent development potentials. The product can not update timely with the progress of science and technology and the changing speed of the visitors' interests. The following suggestions are put forward targeting at the subsequent development of the theme park landscape design, (see Table 2).

\section{The following development measures of theme park landscape design}

Sort out the landscape spatial pattern and increase open activities according to different seasons.

Make good adjustment for the theme park landscape according to the new experiencing and participating games. 
To gradually improve the landscape system of theme parks by integrating the scattered scenic spots.

In the subsequent development of landscape designs of the theme park, more attention should be paid to creativity and exploring historical and cultures.

(Table 2 the following development measures for the landscape design of the theme park)

\section{The Future Development Trend of Urban Theme Park}

\subsection{Part One The Creation of a More In-depth Small Theme Park}

Future Theme Parks in the cities develop towards miniaturization-direction which is more practical and easier to achieve success. Small theme park in the city, though less rich in park contents, less investment and shorter construction period than the large theme park, digs deeper into the theme of each side and adjusts quickly into the direction according to changes in public taste and it has the characteristics of delicacy and flexibility.

The miniaturization of theme park does not mean the reduction in connotation capacity of the theme, so in order to improve the subject form, in-depth themes exploration is still needed. Most of the urban theme construction are subject to the restrictions of capital, scale, type of facilities and technical level. Therefore, it is necessary to avoid weaknesses in the theme development and make full use of local rich cultural resources, relying on the carrier of local culture to reflect the social level and connotation.

\subsection{Part Two The Creation of the More Distinctive Featured City Theme Park}

With the high threshold of city theme park investment, expensive tickets, poor duplicate tourism and the high requirement for theme selection, especially the need of the idea of market value, the failure rate is quite high. And the city theme park based on the local cultural characteristics featured with the low input, is in accordance with the the residents' needs to improve their lives. If we can integrate the local culture into the construction of the city and present the park via the form of tourism products, then the operation of future city theme park will be very unique. However, the construction of a city's theme park, from planning, construction to maturity, needs for a longer time. Therefore, During the process of operation, anxiousness for success should be avoided. In order to achieve a good effect, it is an important part to grasp market trend .

\subsection{Part Three The Creation of a Larger Online Theme Park Market}

The 21st century has witnessed rapid development of Chinese network. The network has had many unique advantages, making it become another emerging power in addition to the traditional media. Theme parks can use the advantages of the network to develop their own strengths. In 2004, in order to match the grand game "world of legend”, Songcheng group jointed with China's largest online-games company, reformed the park which costed the song city's tens of millions investment. This led to the interest of many game users. This move not only attracted the competing reports from a large number of online games industries, but also attracted the attention of the tourism industry. While the overall tourism image of Hangzhou has also been enhanced greatly. More importantly, such a combination indicates that China's theme park can be a breakthrough in the network game and bring new vitality to Chinese theme park in plight. 


\subsection{Part Four The Industrialization of City Theme Park}

Disneyland, as a model of the world theme park, is an everlasting paradise. For many years, Disneyland has been adhering to the principle of "Three-thirds system" which is the elimination of one-third hardware equipment and the establishment of one-third new concept project. Around Disney, a large sports center, many theme hotels, golf club and tennis courts, swimming pool, restaurants and shopping center are constructed there, forming an entirety, thus this has greatly enhanced the Disney World attraction as a tourist destination. Therefore, the development of the future city theme park, must be want of strong economic enterprise groups to carry out industrial expansion and take the scale of operation, industrial management and diversified business road.

\section{Summary}

At present, city theme park is not completely out of predicament. In order to get rid of this situation and win in the fierce market competition, survive and gain profit, the future city theme park must be developed innovatively. In order to breakthrough the bottleneck of its development, the problem must be analyzed one by one. Only in this way, can the problem be solved and a new life be gained.

\section{References}

[1]Wen Li-ling. Where Will the Theme Park be Going-Summary of the Forum on the development of China's Theme Park in Twenty-first Century[J] (in Chinese). Tourism Tribune. Volume $17^{\text {th }}$, 2002(4): 78-79.

[2]Bao Ji-gang, Chu Yifang. Tourism Geography[M] (in Chinese). Beijing: Higher Education Press, 1999.

[3]Chris Cooper, John Fletcher; the main translators: Zhang Lili, Cai Liping. The Principles and Practices of Tourism[M].Beijing:Higher Education Press, 2004.42-43. [4]Zhang Xiao-zhen.The Problems and Development Countermeasures of the theme parks in China[J] (in Chinese).Reform and strategy, 2004(4): 54-56. 